\title{
Blood and urine acid-base status of premenopausal omnivorous and vegetarian women
}

\author{
BY D. BALL* AND R. J. MAUGHAN \\ Department of Environmental and Occupational Medicine, University Medical School, Foresterhill, \\ Aberdeen AB25 2ZD
}

(Received I February 1996 - Revised 3 December 1996 - Accepted 20 February 1997)

\begin{abstract}
The effect of long-term differences in diet composition on whole-body acid-base status was examined in thirty-three young healthy females. The volunteers were recruited from two separate groups matched approximately for age, height and weight; one group regularly ate meat (omnivores; $n$ 20) and one group did not (vegetarians; $n$ 13). All subjects completed a $7 \mathrm{~d}$ weighed intake of food, and from their dietary records, total energy, carbohydrate (CHO), fat and protein content were estimated using computer-based food composition tables. During this week they reported to the laboratory on two occasions, following an overnight fast and separated by at least $48 \mathrm{~h}$. Arterialized venous blood samples were obtained on each visit and these were analysed for blood acid-base status. Haemoglobin and packed cell volume, serum total cholesterol and HDLcholesterol, serum albumin and total protein were also determined. Two $24 \mathrm{~h}$ urine collections were completed; the volume was recorded and samples were analysed for $\mathrm{pH}$, titratable acid and $\mathrm{Mg}$ and Ca concentration. Total energy intake of the omnivores was greater $(P=0.0003)$ than that of the vegetarian group. Dietary intake of $\mathrm{CHO}(P=0.024)$, fat $(P=0.0054)$ and protein $(P=0.0002)$ were higher in the omnivorous group than in the vegetarians. There were no differences between the two groups with respect to blood $\mathrm{CO}_{2}$ partial pressure, plasma $\mathrm{HCO}_{3}{ }^{-}$and blood base excess, but blood pH was slightly higher in the omnivores $(P=0.064)$. Measures of urine acid-base status suggested a lower pH in the omnivore group, but this difference was not statistically significant; a greater titratable acid output was observed with the omnivorous group compared with the vegetarians (48.9 (SE 20.3) $v \cdot 35.3$ (SE 23.3) $\mathrm{mEq} / 24 \mathrm{~h} ; P=0.018$ ). Although the dietary intake of Ca was not different between the two groups, urinary Ca excretion of the omnivores was significantly higher (3.87 (SD 1.34) v. 3.22 (SD 1.20) $\mathrm{mmol} / 24 \mathrm{~h})$ than that of the vegetarians $(P=0.014)$. It is suggested that the higher protein intake of the omnivores resulted in an increase in urinary total acid excretion, which may explain the higher rate of $\mathrm{Ca}$ excretion.
\end{abstract}

Omnivores: Vegetarians: Acid-base status: Titratable acid output: Calcium

Short-term severe dietary manipulation is known to alter blood acid-base status (Greenhaff et $a l .1987 a, b)$. By ingesting a diet which is high in fat and protein and low in carbohydrate (CHO) it is possible to induce an acute mild metabolic acidosis. It is believed that the cause of the metabolic acidosis is an increase in circulating non-volatile weak acids resulting from the increased dietary intake of protein (Greenhaff et al. 1988). These studies were, however, conducted only over a 3 or $4 \mathrm{~d}$ period, and whether a long term alteration in acidbase status would persist if such a dietary regimen were to be maintained is unknown. A vegetarian diet can be categorized under one of three classifications: a demivegetarian diet is a vegetable diet supplemented with fish, milk, dairy products and eggs; a lacto-ovo vegetarian diet contains vegetables supplemented with milk, dairy products and eggs; a pure

* Present address: Neuromuscular Biology Group, Crewe and Alsager Faculty, Manchester Metropolitan University, Hassall Road, Alsager, ST7 2HL. 
vegetarian diet, also referred to as a vegan diet, contains no animal products (Wilson et al. 1975; Draper et al. 1990). There have been several reports of differences in the composition of the diet between omnivores and vegetarians, with omnivores having a higher daily protein intake than vegetarians (Taber \& Cook, 1980; Shultz \& Leklem, 1983; Tylavsky \& Anderson, 1988). Increases in dietary protein intake while eating a mixed diet have also been reported to exert an acidifying effect on urine (Hunt, 1956; Lutz, 1984; Breslau et al. 1988). This is characterized by an increase in titratable acid output (Hunt, 1956; Lutz, 1984; Breslau et al. 1988) and in some cases by a decrease in urinary pH (Hunt, 1956; Kurtz et al. 1983).

Sherman \& Gettler (1912) suggested that the acidity or alkalinity of the residual ash of dietary components following combustion should allow assumptions to be made concerning the effect of diet on urine acid-base status. The food composition tables from which these assumptions were made had been used, without question, for almost 75 years. Dwyer et al. (1985) re-assessed the validity of the assumptions of Sherman \& Gettler (1912) using data based on current food composition tables. The alkaline- and acid-ash contents of the three different diets were calculated from data derived from several different food composition tables (cf. Dwyer et al. 1985). It was reported that vegetarian and vegan diets had a higher alkaline ash than omnivore diets but that the estimates were not sufficiently reliable to allow assumptions to be made concerning urinary $\mathrm{pH}$ (Dwyer et al. 1985).

To our knowledge the blood and urine acid-base status of vegetarians has not been investigated. The present study was designed to compare two groups of individuals who had long-term differences in dietary habits, vegetarian and omnivorous, and the effect of those diets on whole-body acid-base status.

\section{MATERIALS AND METHODS}

\section{Subjects}

Thirty-three healthy females volunteered to participate in the present study. Their age, height, weight and estimated percentage body fat are given in Table 1. Of this total group of females, twenty regularly ate meat whilst the remaining thirteen were classified as vegetarians (i. e. they consumed some dairy products but no meat). Although two of the vegetarian subjects occasionally ate fish, neither did so during the week of the study. The study had been approved by the local ethics committee and each subject provided written informed consent before participating in the study, after having been given a full explanation of all experimental procedures and of the need to adhere to the stringent experimental criteria.

\section{Experimental protocol}

All subjects weighed and recorded their intake of food (including drinks) for a period of seven consecutive days; this included all alcohol consumed and in addition any vitamin supplements and medication that they were taking. From these records their daily intake of food was assessed using the computerized microdiet system based on McCance and Widdowson's food composition tables (Paul \& Southgate, 1983). Subsequent analysis was carried out to determine the contribution of the macronutrients to the diet as a percentage of total energy intake. 
Table 1. Physical characteristics and daily dietary intake of the omnivorous and vegetarian women participating in the study

(Mean values and standard deviations)

\begin{tabular}{|c|c|c|c|c|c|}
\hline & \multicolumn{2}{|c|}{ Omnivores ( $n$ 20) } & \multicolumn{2}{|c|}{ Vegetarians ( $n$ 13) } & \multirow{2}{*}{$\begin{array}{c}\text { Statistical significance } \\
\text { of difference between groups: } P\end{array}$} \\
\hline & Mean & $\mathrm{SD}$ & Mean & SD & \\
\hline Age (years) & 23 & 5 & 24 & 5 & 0.24 \\
\hline Height (m) & 1.66 & 0.06 & 1.64 & 0.08 & 0.58 \\
\hline Wt $(\mathrm{kg})$ & 60.9 & 4.5 & 57.7 & $2 \cdot 1$ & 0.71 \\
\hline Body fat (\%) & 25.9 & $3 \cdot 5$ & $25 \cdot 0$ & $5 \cdot 0$ & 0.97 \\
\hline Energy intake (MJ) & $9 \cdot 1$ & 1.5 & $7 \cdot 2$ & $1 \cdot 1$ & 0.0003 \\
\hline Protein $(\mathrm{g})$ & 69.9 & 8.8 & $55 \cdot 1$ & $10 \cdot 0$ & 0.0002 \\
\hline Fat $(\mathrm{g})$ & $88 \cdot 3$ & $18 \cdot 0$ & 65.4 & $22 \cdot 2$ & 0.0054 \\
\hline $\mathrm{CHO}(\mathrm{g})$ & 279 & 69.1 & 227 & $26 \cdot 1$ & 0.024 \\
\hline Alcohol (g) & 5.9 & 6.6 & 7.9 & $6 \cdot 7$ & 0.51 \\
\hline Protein (\% of energy) & $12 \cdot 9$ & & $12 \cdot 8$ & & 0.60 \\
\hline Fat (\% of energy) & 36.6 & & $34 \cdot 1$ & & 0.16 \\
\hline $\mathrm{CHO}$ (\% of energy) & 48.2 & & 49.5 & & 0.31 \\
\hline Alcohol (\% of energy) & $2 \cdot 3$ & & 3.6 & & $0 \cdot 16$ \\
\hline
\end{tabular}

\section{Body composition}

On their first visit to the laboratory each subject's height and weight were measured. An estimation of their percentage body fat was made from the sum of four skinfold measurements (triceps, biceps, supra-iliac and subscapular) using the procedures and the equations described by Durnin \& Womersley (1974).

\section{Blood sample collection and analysis}

On two separate occasions during the week of their weighed food intake, subjects were asked to report to the laboratory in the morning after an overnight fast. An arterialized venous blood sample (Forster et al. 1972) was taken from a superficial vein on the dorsal part of the heated hand; before the sample was collected, subjects rested for at least $15 \mathrm{~min}$ in a seated position with the hand immersed in water maintained at a temperature of $42^{\circ}$. A sample $(2.5 \mathrm{ml})$ of blood was collected anaerobically in a heparinized syringe, capped and kept on iced water and analysed within $2 \mathrm{~h}$ for $\mathrm{pH}$, partial pressure (p) for $\mathrm{CO}_{2}$ and $\mathrm{pO}_{2}$, using a Radiometer BMS3 MK2 blood gas analyser (Radiometer, Copenhagen, Denmark). It should be noted that the use of arterialized venous blood will consistently overestimate $\mathrm{pCO}_{2}$, by approximately $0.13 \mathrm{kPa}$, and underestimate $\mathrm{pH}$, by 0.005 units, compared with values observed from arterial blood (Forster et al . 1972). Plasma bicarbonate $\left(\mathrm{HCO}_{3}{ }^{-}\right)$and blood base excess (BE) values were calculated according to Siggaard-Andersen (1963).

A further $10 \mathrm{ml}$ blood sample was collected: of this, one portion $(2.5 \mathrm{ml})$ was mixed with $\mathrm{K}_{3}$ EDTA $(1 \mathrm{mg} / \mathrm{ml})$. This sample was used to determine haemoglobin concentration by the cyanomethaemoglobin technique (Drabkin \& Austin, 1935) and packed cell volume by the microcapillary centrifugation method (Hawksley, Lancing, Sussex). Erythrocyte and leucocyte counts were measured using a Coulter Counter (Coulter Electronics, Dunstable, Beds.). The remaining $7.5 \mathrm{ml}$ blood was put into a plain tube and allowed to clot; the serum was then separated by centrifugation and analysed for total cholesterol and HDLcholesterol content (kit no. 071106 3; Roche Diagnostics, Welwyn Garden City, Herts.), 
total protein concentration (Boehringer Corp, Lewes, Sussex) and serum albumin (kit no. 071472 0; Roche Diagnostics).

\section{Urine samples}

Subjects were asked to provide two $24 \mathrm{~h}$ urine samples during the week of their weighed intake. Each collection began in the morning on the day before the blood sampling and finished on the morning of the blood sample. Urine was collected in plain containers. The volume of urine was measured using a 1 litre measuring cylinder and then thoroughly mixed in order to re-suspend any precipitate. The $\mathrm{pH}$ of the urine sample was measured using a Russell electrode (type CTWL; Russell Electrodes, Fife) and a Corning $140 \mathrm{pH}$ meter (Corning Science Products, Halstead, Essex). Total acid content was determined by titration using the method described by Jorgensen (1957). Two $20 \mathrm{ml}$ portions were stored: one of these was acidified with $1 \mathrm{M}-\mathrm{HCl}$ to a pH below 3 and both were frozen. The samples were later analysed for $\mathrm{Ca}$ (kit no. 071028 8; Roche Diagnostics) and Mg concentration (kit no. E36742; Ciba-Corning, Halstead, Essex).

\section{Statistical analysis}

The CV was calculated for several analytical methods from duplicate measurements; blood $\mathrm{pH} n 50, \mathrm{CV} 0.0 \%$; $\mathrm{pCO}_{2} n 50, \mathrm{CV} 1.6 \%$; blood haemoglobin $n 50, \mathrm{CV} 0.7 \%$; plasma protein $n 50, \mathrm{CV} 1 \cdot 1 \%$; urine $\mathrm{pH} n 55, \mathrm{CV} 0.3 \%$; urine titratable acid $n 40$, CV $2 \cdot 1 \%$, urine $\mathrm{Ca} n 55, \mathrm{CV} 1.7 \%$, urine $\mathrm{Mg} n 55, \mathrm{CV} 2.7 \%$. Before performing any inferential statistical test, data were checked for normality of distribution. Statistical analysis was by Student's $t$ test for paired and unpaired data as appropriate. Data are expressed as means and standard deviations except in Fig. 1 in which, for reasons of clarity, values are expressed as means with their standard errors.

\section{RESULTS}

\section{Anthropometric characteristics}

Statistical analysis of the physical characteristics of the two groups did not reveal any differences between them with respect to height, weight, or percentage body fat (Table 1).

\section{Dietary intake and composition}

Analysis of the dietary records provided by the two groups of subjects demonstrated that there were differences of approximately $2 \mathrm{MJ} / \mathrm{d}$ in overall energy intake (Table 1); this was a direct result of a difference in macronutrient intake. The total energy intake for the omnivores was calculated to be 9.1 (SD 1.5) $\mathrm{MJ} / \mathrm{d}$, which was greater $(P=0.0003)$ than the intake $(7.2$ (SD 1.1) $\mathrm{MJ} / \mathrm{d})$ of the vegetarians.

The mean daily fat intake of the omnivores was 88 (SD 18) $\mathrm{g} / \mathrm{d}$ and was found to be higher $(P=0.0054)$ than that of the vegetarian subjects (65 (SD 22) g/d). Similarly, the protein intake of the omnivorous group (70 (SD 9) g/d) was greater $(P=0.0002)$ than that of the vegetarian subjects (55 (SD 10) g/d). The amount of CHO reported to be consumed daily by the omnivores was 279 (SD 69) $\mathrm{g} / \mathrm{d}$ and this was also found to be greater $(P=0.024)$ than that $(227$ (SD 26) $\mathrm{g} / \mathrm{d})$ of the vegetarians (Table 1). There was no difference in alcohol intake between the omnivores $(5.9$ (SD 6.6) $\mathrm{g} / \mathrm{d}$ ) and vegetarians $(7.9$ $(\mathrm{SD} 6.7) \mathrm{g} / \mathrm{d}$ ). When the macronutrient intakes of the respective groups are expressed as a percentage of the total energy intake, the diet composition of the two groups was not different (Table 1). 
Comparison of the daily dietary intake of $\mathrm{Ca}$ and $\mathrm{P}$ failed to show any differences between the two groups despite the observed differences in total energy intake (Table 2); however, the dietary intake of $\mathrm{Mg}$ was higher in the vegetarian subjects $(P=0.05)$. The estimated $\mathrm{N}$ intake of the omnivorous group was 11 (SD 2) g/d, which was higher $(P=0.013)$ than that $(9$ (SD 2) g/d) of the vegetarian subjects; this is a direct result of the greater protein intake of the omnivores. There were three subjects (one vegetarian and two omnivores) who at the time of the study were taking dietary supplements; two subjects supplemented their diet with multi-vitamins and $\mathrm{Fe}$, while the remaining subject took evening primrose (Oenothera biennis) oil and ginseng. One subject (vegetarian) was taking medication (antibiotics) during the course of the study.

An estimation of the alkaline- and acid-ash contents of the diets was made (Sherman \& Gettler, 1912; Hunt, 1956; Dwyer et al. 1985) based on the sum of the cations minus the anion content of the diets. The cations and anions were converted into mmol from $\mathrm{mg}$ by dividing by their atomic mass and then to $\mathrm{mEq}$ by multiplying the mmol value by the respective valence. An average value of 1.8 was used for the valence of $P$ since it can be found in mono-, di-, and tri-valent forms in body fluids (Shohl, 1923). Comparison of the diets showed that there was a large individual variation in both groups; the vegetarian diet had a higher alkaline-ash content $(51.8$ (SD 25.1$) \mathrm{mEq} / 24 \mathrm{~h}$ ) than the omnivorous diet ( 42.4 (SD 24.1$) \mathrm{mEq} / 24 \mathrm{~h}$ ), but following log transformation of these data, statistical analysis failed to show a significant difference $(P=0 \cdot 098)$.

\section{Blood acid-base status}

The day-to-day variation in acid-base status of each group was compared before making comparison between the two groups. The day to day variation with respect to each of the acid-base variables was small and not statistically significant within either of the two groups. The plasma $\mathrm{HCO}_{3}{ }^{-}(\mathrm{mmol} / \mathrm{l})$ on each of the $2 \mathrm{~d}$ for the omnivores was 19.5 (SD 1.4 ) on day 1 and 19.9 (SD 1.1) on day 2 and for the vegetarians 19.9 (SD 1.7) on day 1 and 19.8 (SD 1.1) on day 2. Blood BE values on days 1 and 2 were -4.1 (SD 1.2) and -3.7 (SD 0.9 ) $\mathrm{mmol} / \mathrm{l}$ respectively for the omnivores and -3.7 (SD 1.4) and -4.1 (SD 0.9)

Table 2. Daily intake of dietary minerals $(\mathrm{mmol} / 24 \mathrm{~h})$ and urinary excretion of calcium and magnesium (mmol/24 h) of premenopausal omnivorous and vegetarian women*

(Mean values and standard deviations)

\begin{tabular}{|c|c|c|c|c|c|}
\hline & \multicolumn{2}{|c|}{ Omnivores $(n$ 20) } & \multicolumn{2}{|c|}{ Vegetarians ( $n$ 13) } & \multirow{2}{*}{$\begin{array}{l}\text { Statistical significance } \\
\text { of difference between } \\
\text { groups: } P\end{array}$} \\
\hline & Mean & SD & Mean & SD & \\
\hline \multicolumn{6}{|c|}{ Dietary intake of: } \\
\hline $\mathrm{Na}$ & 117 & 29 & 93 & 32 & 0.039 \\
\hline $\mathrm{K}$ & 72 & 17 & 78 & 13 & 0.47 \\
\hline $\mathrm{Ca}$ & 24.4 & $6 \cdot 1$ & 25.4 & 7.7 & 0.63 \\
\hline $\mathrm{Mg}$ & 10.9 & 3.3 & $12 \cdot 8$ & $2 \cdot 3$ & 0.05 \\
\hline $\mathbf{P}$ & 40.4 & $2 \cdot 4$ & $40 \cdot 4$ & 2.4 & 0.95 \\
\hline$s$ & 29.0 & 8.9 & 25.6 & $6 \cdot 1$ & 0.19 \\
\hline $\mathrm{Cl}$ & 115 & 24 & 99 & 27 & 0.083 \\
\hline \multicolumn{6}{|c|}{ Urinary excretion of: } \\
\hline $\mathrm{Ca}$ & 3.87 & 1.34 & $3 \cdot 22$ & 1.20 & 0.014 \\
\hline $\mathrm{Mg}$ & $4 \cdot 10$ & 1.43 & 3.67 & 1.61 & 0.12 \\
\hline
\end{tabular}

* For details of subjects and procedures, see Table 1 and pp. 684-686. 
$\mathrm{mmol} / \mathrm{l}$ respectively for the vegetarians. The mean values for each of these variables were subsequently used for statistical analysis.

A small but significant difference $(P=0.05)$ was found between the groups with respect to blood $\mathrm{pH}$. The blood $\mathrm{pH}$ of the omnivorous group of subjects was higher $(7.41$ (SD 0.02)) compared with that of the vegetarians (7.40 (SD 0.01); Table 3). The other measured and calculated blood acid-base variables were not different between the two groups (Table 3).

\section{Haematological and plasma variables}

There were no differences between the day 1 and day 2 samples with respect to haemoglobin, packed cell volume, total cholesterol, HDL-cholesterol of the concentration of total protein or albumin. With the exception of plasma cholesterol there was no difference between the two groups with respect to these variables. The vegetarians had a significantly higher plasma total cholesterol concentration than did the omnivores $(P=0.023$; Table 3). In the present study, LDL-cholesterol concentration was not measured and there was no difference in HDL-cholesterol concentration between groups.

\section{Urine acid-base status}

Comparison of the variation between sample days 1 and 2 in urinary $\mathrm{pH}$ and titratable acid of the two groups did not reveal any statistical significant differences between the two measurements. Although there was no significant difference in urinary $\mathrm{pH}$ between the two groups, the omnivores tended to have a lower urinary $\mathrm{pH}$ (day 16.26 (SD 0.11 ), day 26.26 (SD 0.11)) than the vegetarians (day 16.52 (SD 0.15), day 26.38 (SD 0.16 ); $P=0.17$ ). The urinary titratable acid output of the omnivores was 48.9 (SD 20.3) $\mathrm{mEq} / 24 \mathrm{~h}$, compared with 35.3 (SD 23.3) $\mathrm{mEq} / 24 \mathrm{~h}$ for the vegetarians $(P=0.014$; Fig. 1).

\section{Urinary excretion of calcium and magnesium}

Comparison of the urinary excretion of $\mathrm{Ca}$ and $\mathrm{Mg}$ did not reveal a difference between the two $24 \mathrm{~h}$ collections for the whole subject population. When the values were compared between groups, the omnivores had a higher daily urinary excretion of $\mathrm{Ca}$ than the vegetarians $(P=0.014$; Table 2$)$. The urinary excretion of $\mathrm{Mg}$ was found not to be different between the two groups (Table 2).

\section{DISCUSSION}

The findings of the present experiment demonstrate significant differences in total energy intake and dietary macronutrient content between the vegetarian and omnivorous subjects, although the composition of the diet expressed as the percentage contribution of the macronutrients to total energy intake was not different between the two groups. There were also differences in blood and urinary acid-base status between the groups, with the vegetarians demonstrating a more alkaline urine. Furthermore, the daily urinary excretion of Ca by the omnivorous subjects was higher than that of the vegetarian group, despite the dietary intake of $\mathrm{Ca}$ being the same. It is postulated that the higher dietary protein intake of the omnivorous group was responsible for their higher urinary acid output and that this caused an increased rate of $\mathrm{Ca}$ excretion. 


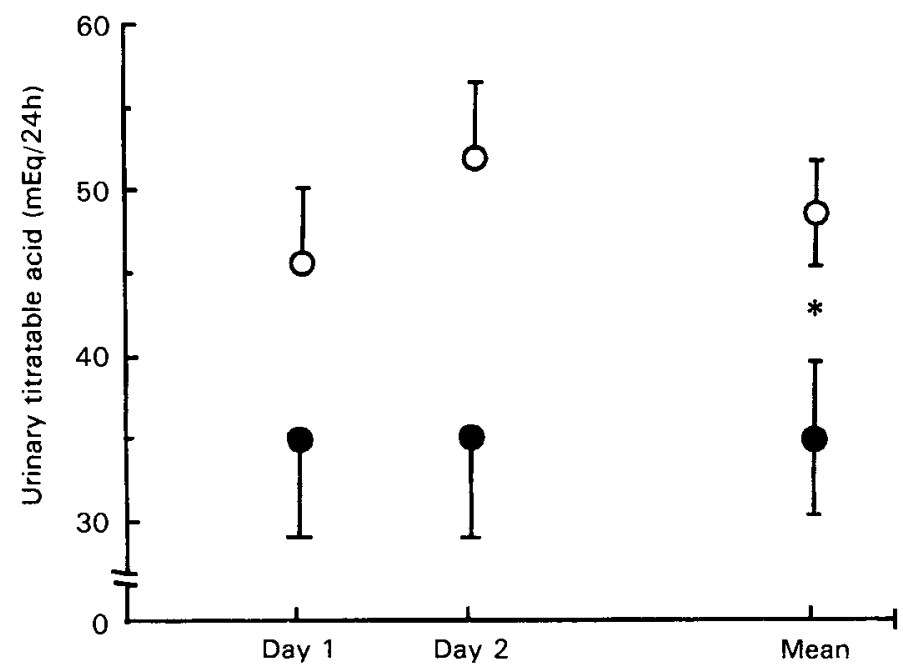

Fig. 1. Variability between sampling days 1 and 2 and mean values for both days for urinary titratable acid output $(\mathrm{mEq} / 24 \mathrm{~h}$ ) for premenopausal omnivorous $(\mathrm{O})$ and vegetarian $(O)$ women. Values are means with their standard errors represented by vertical bars for twenty omnivores and thirteen vegetarians. Mean values were significantly different between groups: ${ }^{*} P=0 \cdot 014$. For details of subjects and procedures, see Table 1 and pp. 684-686.

The total energy intake of the two groups was different $(P=0.0003)$, with the energy intake of the omnivores being almost $2 \mathrm{MJ} / \mathrm{d}$ higher. The total energy intake of the vegetarian subjects was reported as 7.2 (SD 1.1) MJ/d. Although this value for total energy intake appears low, previously-reported energy intakes of vegetarians are generally similar. The energy intake of Seventh-day Adventist vegetarians, based on a $3 \mathrm{~d}$ dietary record, was 7.4 (SD 1.7) MJ/d; this was not different from the energy intake (7.7 (SD 1.6) MJ/d) of non-

Table 3. Haematological, plasma protein and lipid variables and resting plasma $p H$, partial pressure $(p)$ of carbon dioxide, bicarbonate ions and base excess $(B E)$ for premenopausal omnivorous and vegetarian women*

(Mean values and standard deviations)

\begin{tabular}{|c|c|c|c|c|c|}
\hline & \multicolumn{2}{|c|}{ Omnivores ( $n$ 20) } & \multicolumn{2}{|c|}{ Vegetarians (n 13) } & \multirow{2}{*}{$\begin{array}{c}\text { Statistical significance of } \\
\text { difference between } \\
\text { groups: } P\end{array}$} \\
\hline & Mean & SD & Mean & SD & \\
\hline $\mathrm{Hb}(\mathrm{g} / \mathrm{l})$ & 115 & 9 & 116 & 11 & 0.43 \\
\hline $\operatorname{PCV}(\%)$ & 39.4 & 2.0 & $39 \cdot 4$ & $2 \cdot 5$ & 0.79 \\
\hline Total protein $(\mathrm{g} / \mathrm{l})$ & $70 \cdot 9$ & 6.6 & 70.9 & 6.3 & 0.85 \\
\hline Albumin $(\mathrm{g} / \mathrm{l})$ & $47 \cdot 2$ & $4 \cdot 4$ & 47.9 & 4.5 & $0 \cdot 10$ \\
\hline Cholesterol $(\mathrm{mmol} / \mathrm{l})$ & 4.03 & 0.73 & $4 \cdot 54$ & 0.62 & 0.023 \\
\hline $\mathrm{HDL}(\mathrm{mmol} / \mathrm{l})$ & 1.58 & 0.26 & 1.63 & 0.35 & 0.69 \\
\hline $\mathrm{pH}$ & 7.41 & 0.02 & 7.40 & 0.01 & 0.05 \\
\hline $\mathrm{pCO}_{2}(\mathrm{kPa})$ & $4 \cdot 21$ & 0.32 & $4 \cdot 32$ & 0.23 & 0.47 \\
\hline $\mathrm{HCO}_{3}^{-}(\mathrm{mmol} / 1)$ & 19.7 & $1 \cdot 3$ & 19.9 & 1.3 & 0.78 \\
\hline $\mathrm{BE}(\mathrm{mmol} / \mathrm{l})$ & $-3 \cdot 8$ & $1 \cdot 2$ & $-3 \cdot 8$ & $1 \cdot 1$ & 1.0 \\
\hline
\end{tabular}

$\mathrm{Hb}$, haemoglobin; $\mathrm{PCV}$, packed cell volume.

* For details of subjects and procedures, see Table 1 and pp. 684-686. 
vegetarian Seventh-day Adventists (Shultz \& Leklem, 1983). One other study also found that energy intakes were not different between vegetarians and omnivores, based on $3 \mathrm{~d}$ food records and food-frequency questionnaires (Taber \& Cook, 1980). Demi-vegetarians were reported to have an average daily energy intake of 8.0 (SE 2.6) $\mathrm{MJ} / \mathrm{d}$ and lacto-ovovegetarians of 7.7 (SE 2.5) MJ/d based on a $3 \mathrm{~d}$ weighed intake of food (Draper \& Wheeler, 1990). Vegetarians completing a $7 \mathrm{~d}$ weighed intake of food were reported to have an average energy intake of 8.1 (SE 0.9) (Roberts \& Mathers, 1990). In addition, a recent study (Ramsdale \& Bassey, 1994) based on a 3d weighed intake reported energy intakes of 7.9 (SE 0.3) $\mathrm{MJ} / \mathrm{d}$ for a group of women of a similar age range (18-44 years) but with a higher body mass $(67.3$ (SE 1.0) $\mathrm{kg}$ ) compared with those in the present study.

The low dietary energy intake of the vegetarians highlights the difficulties encountered by the present study and those of other authors in obtaining a reliable estimate of energy intake based on a record of the $7 \mathrm{~d}$ weighed intake of food. Using the doubly-labelled-water technique discrepancies between reported energy intake and energy expenditure in men and women have been reported (Livingstone et al. 1990). Calculation of the BMR from age, height and body mass (Schofield et al. 1985) demonstrates that the BMR of the two present groups should be similar; 5.87 (SE 0.49) MJ/d for the omnivore subjects and 5.69 (SD 0.44) $\mathrm{MJ} / \mathrm{d}$ for the vegetarians. The minimum energy expenditure of sedentary individuals is reported to be $1.3 \times \mathrm{BMR}$ (Prentice et al. 1985). The reported energy intake of the subjects in the present study was calculated to be 1.55 (SD 0.25$) \times$ estimated BMR for the omnivorous subjects and 1.27 (SD 0.20) $\times$ BMR for the vegetarians. The low energy intakes of the vegetarians may be a case of under-reporting or may be the result of an unconscious change in their normal dietary pattern. The alternative explanation is that they do indeed have a lower energy requirement, perhaps related to a lower level of physical activity. Since the importance of recording everything they ate was emphasized to the subjects, the low energy intake reported is more likely to be a consequence of an unconscious change in dietary pattern.

It is widely reported that omnivores have, on average, a higher daily protein intake than vegetarians (Taber \& Cook, 1980; Shultz \& Leklem, 1983; Tylavsky \& Anderson, 1988). In the present study the mean dietary intake of protein of the omnivores (70 (SD 9) $\mathrm{g} / \mathrm{d}$ ) was almost $15 \mathrm{~g} / \mathrm{d}$ greater than that of the vegetarians. An acute increase in dietary protein intake is reported to have an acidifying effect on blood (Kurtz et al. 1983; Greenhaff et al. 1987a,b, 1988). The diet regimen that was employed by Greenhaff et al. $(1987 a, b)$ was high in protein ( $>29 \%$ of total energy), high in fat $(>64 \%)$ and low in carbohydrate $(<10 \%)$ and the diets were isoenergetic with each subject's normal intake; adherence to this regimen resulted in inducing a mild metabolic acidosis. The increases in circulating $\beta$-hydroxybutyrate and free fatty acid concentration while consuming these high-fat-high-protein diets are similar to the changes in metabolite concentration following a $24 \mathrm{~h}$ fast (Maughan, 1978). The reported changes in these metabolites have been described as ketoacidosis normally found during fasting (Rose, 1977). Altering dietary composition by reducing the $\mathrm{CHO}$ content and increasing the protein content of two experimental diets for $10 \mathrm{~d}$ was reported to reduce plasma $\mathrm{HCO}_{3}{ }^{-}$concentration and lower plasma $\mathrm{pH}$ while subjects consumed the lower CHO diet (Kurtz et al. 1983). Despite the significant differences in fat and protein intake between the two groups of subjects in the present study, the only difference in blood acid-base status was the lower plasma $\mathrm{pH}$ of the vegetarians; this small difference, although statistically significant, is probably of little biological importance.

Increases in dietary protein intake have also been reported to exert an acidifying effect on urine (Hunt, 1956; Lutz, 1984; Breslau et al. 1988). This is characterized by an increase 
in titratable acid output (Hunt, 1956; Lutz, 1984; Breslau et al. 1988) and in some cases by a decrease in urinary pH (Hunt, 1956; Kurtz et al. 1983). As reported in the present study the titratable acid output of the omnivores was on average $13.3 \mathrm{mEq} / \mathrm{d}$ higher than that of the vegetarians. The acidifying effect of the increased dietary protein intake is probably a direct result of the metabolism of the S-containing amino acids, cysteine, cystine and methionine (Sherman, 1941; Hunt, 1956, Lemann \& Relman, 1959).

Not all the net urinary acid excretion can be accounted for by the metabolism of the $S$ containing amino acids (Lemann \& Relman, 1959). The alkaline- and acid-ash theory of dietary components influencing urinary acid-base status was first proposed by Sherman \& Gettler (1912) but was subsequently questioned by Hunt (1956) and Lemann et al. (1965) when they reported that the alkaline- or acid-ash content of diet failed to fully account for all acid production from the oxidation of the diet. Halperin (1982) identified the need to take into account the metabolism of other amino acids that consume $\mathrm{H}^{+}$(glutamate and aspartate) and the metabolism of organic anions such as acetate, citrate, malate and tartrate. In the present study, it was calculated from the cation and anion content of the diets that the alkaline-ash content of the vegetarian diet appeared to be $18 \%$ greater than that of the omnivore diet. The absolute difference between the two diets was calculated to be about 9 $\mathrm{mEq} / \mathrm{d}$. Titratable acid output of the omnivores was $28 \%$ higher than that of the vegetarians; an absolute difference of $13.6 \mathrm{mEq} / \mathrm{d}$.

The difference in dietary protein intake between the diets of the two subject groups was $14.8 \mathrm{~g} / \mathrm{d}$. The amino acid composition of vegetable and animal proteins also differs. Animal protein has a higher cystine and methionine content than vegetable protein and this difference should be reflected, therefore, in a higher dietary content of $S$. The $S$ content of the diet of omnivorous subjects was calculated to be $12 \%$ greater than that of the vegetarian diet. The absolute difference in $S$ content between the two diets was calculated to be $3.4 \mathrm{mEq} / \mathrm{d}$. These data demonstrate that the higher titratable acid output of the omnivores may be related as much to the lower alkaline ash content of the diet as to the higher protein and $\mathrm{S}$ content.

Several dietary factors are known to cause hypercalciuria in both human subjects and animals; these include protein, $\mathrm{Na}$ and $\mathrm{S}$ intake (Block et al. 1980; Linkswiler et al. 1981; Breslau et al. 1988; Hu et al. 1993; Chan \& Swaminathan, 1994). The urinary excretion of $\mathrm{Ca}$ is reported to increase when the dietary protein intake is increased (Wachman \& Bernstein, 1968; Allen et al. 1979; Hegsted \& Linkswiler, 1981; Linkswiler et al. 1981; Lutz, 1984; Anderson et al. 1987; Kerstetter \& Allen, 1990). The link between an increase in urinary excretion of $\mathrm{Ca}$ and dietary protein intake has been postulated to be related to the metabolism of the S-containing amino acids and the excretion of the strong inorganic acids so formed. It is well documented that an increase in the $S$ content of the diet produces a hypercalciuric effect (Hunt, 1956; Lemann \& Relman, 1959; Block et al. 1980). The suggestion that changes in acid-base status can affect the excretion of $\mathrm{Ca}$ does not appear to be too tenuous considering the circumstantial evidence which demonstrates a reduction in urinary calcium excretion following the administration of alkalizing agents (Sakahee et al. 1983; Lutz, 1984; Lemann et al. 1989). Despite a similar Ca intake between the two groups, the urinary excretion of $\mathrm{Ca}$ was higher in the omnivore group. This could also be related to a higher intake of $\mathrm{NaCl}$. The daily intake of $\mathrm{Na}$ in the omnivores was 117 (SD 29) $\mathrm{mmol} / 24 \mathrm{~h}$ which was $25 \%$ higher $(P<0.05)$ than the intake of the vegetarians $(93$ (SD 32) $\mathrm{mmol} / 24 \mathrm{~h}$ ). It is known that $\mathrm{Na}$ has a hypercalciuric effect (Chan \& Swaminathan, 1994) that is thought to be due to a reduction in renal $\mathrm{Ca}$ absorption accompanying a reduction in $\mathrm{Na}$ re-absorption (Chan et al. 1992). In rats a significant interaction between a high protein intake and high $\mathrm{Na}$ intake was reported to reduce the renal absorption of $\mathrm{Ca}$ (Chan \& 
Swaminathan, 1994). In the present study both protein and $\mathrm{Na}$ intake were higher in the omnivorous subjects compared with the vegetarians and the interaction between these two factors could explain the increased excretion of Ca despite similar dietary intake.

The present findings support earlier reports which have shown that acidification of urine results in an increased Ca excretion. In the present study, however, the differences between subject groups are due to differences in the self-selected diets. The higher dietary intake of protein by the omnivores was the possible cause of the increased urinary output of titratable acid and, hence, the elevated excretion of Ca despite similar dietary intakes of $\mathrm{Ca}$.

The authors wish to thank Mr J. B. Leiper and Mr G. Henderson for technical assistance during this study, and $\mathrm{Mr}$ A. Batterham for advice concerning the statistical analysis. D. B. was supported by a grant from Callitheke UK Ltd.

\section{REFERENCES}

Allen, L. H., Oddoye, E. A. \& Margen, S. (1979). Protein-induced hypercalciuria: a longer term study. American Journal of Clinical Nutrition 32, 741-749.

Anderson, J. J. B., Thomsen, K. \& Christiansen, C. (1987). High protein meals, insular hormones and urinary calcium excretion in human subjects. In Osteoporosis 1987 [C. Christiansen, J. Johansen and B. J. Riis, editors]. Copenhagen: Osteopress Aps.

Block, G. D., Wood, R. J. \& Allen, L. H. (1980). A comparison of the effects of feeding sulfur amino acids and protein on urine calcium in man. American Journal of Clinical Nutrition 33, 2128-2136.

Breslau, N. A., Brinkley, L., Hill, K. D. \& Pak, C. Y. C. (1988). Relationship of animal protein-rich diet to kidney stone formation and calcium metabolism. Journal of Clinical Endocrinology and Metabolism 66, 140146.

Chan, E. L. P., Ho, C. S., MacDonald, D., Ho, S. C., Chan, T. Y. K. \& Swaminathan, R. (1992). Interrelationships between urinary sodium, calcium, hydroxyproline and serum PTH in healthy subjects. Acta Endocrinologica 927, 242-245.

Chan, E. L.P. \& Swaminathan, R. (1994). The effect of high protein and high salt intake for 4 months on calcium and hydroxyproline excretion in normal and oophorectomized rats. Joumal of Laboratory and Clinical Medicine 124, 37-41.

Drabkin, D. L. \& Austin, J. H. (1935). Spectrophotometric studies, II. Preparations from washed blood cells; nitric oxide hemoglobin, and sulfhemoglobin. Journal of Biological Chemistry 112, 51.

Draper, A., Wheeler, E. F. \& Lewis, J. (1990). What do 'vegetarians' eat? Proceedings of the Nutrition Society 49, 60A.

Dwyer, J., Foulkes, E., Evans, M. \& Ausman, L. (1985). Acid/alkaline ash diets: time for assessment and change. Journal of the American Dietetic Association 85, 841-845.

Durnin, J. V. G. A. \& Womersley, J. (1974). Body fat assessed from total body density and its estimation from skinfold thickness: measurement on 481 men and women aged from 16 to 72 years. British Journal of Nutrition 32, 77-97.

Forster, H. V., Dempsey, J. A., Thomson, J., Vidruk, R. \& DoPico, G. A. (1972). Estimation of arterial $\mathrm{PO}_{2}$, $\mathrm{PCO}_{2}, \mathrm{pH}$ and lactate from arterialised venous blood. Journal of Applied Physiology 32, 134-137.

Greenhaff, P. L., Gleeson, M. \& Maughan, R. J. (1987a). The effects of dietary manipulation on blood acid-base status and the performance of high intensity exercise. European Journal of Applied Physiology 56, 331-337.

Greenhaff, P. L., Gleeson, M. \& Maughan, R. J. (1988). The effects of a glycogen loading regimen on blood acid-base status and blood lactate concentration before and after a fixed period of high intensity exercise in man. European Journal of Applied Physiology 57, 254-259.

Greenhaff, P. L., Gleeson, M., Whiting, P. H. \& Maughan, R. J. (1987b). Dietary composition and acid-base status: limiting factors in the performance of maximal exercise in man? European Journal of Applied Physiology 56, 444-450.

Halperin, M. L. (1982). Metabolism and acid-base physiology. Artificial Organs 6, 357-362.

Hegsted, M. \& Linkswiler, H. M. (1981). Long-term effects of level of protein intake on calcium metabolism in young adult women. Journal of Nutrition 111, $244-251$.

Hu, J. F., Zhao, X. H., Parpia, B. \& Campbell, T. C. (1993). Dietary intakes and urinary excretion of calcium and acids: a cross-sectional study of women in China. American Journal of Clinical Nutrition 58, 398-406.

Hunt, J. N. (1956). The influence of dietary sulphur on the urinary output of acid in man. Clinical Science 15, $119-134$.

Jorgensen, K. (1957). Titrimetric determination of the net excretion of acid/base in urine. Scandinavian Journal of Clinical Laboratory Investigation 9, 287-291. 
Kerstetter, J. E. \& Allen, L. H. (1990). Dietary protein increases urinary calcium. Journal of Nutrition 120, 134 135.

Kurtz, I., Maher, T., Hulter, H. N., Schambelan, M. \& Sebastian, A. (1983). Effect of diet on plasma acid-base composition in normal humans. Kidney International 24, 670-680.

Lemann, J. Jr, Gray, R. W. \& Pleuss, J. A. (1989). Potassium bicarbonate, but not sodium bicarbonate, reduces urinary calcium excretion and improves calcium balance in healthy men. Kidney International 35, 688-695.

Lemann, J. Jr, Lennon, E. J., Goodman, A. D., Liztow, J. R. \& Relman, R. S. (1965). The net balance of acid in subjects given large loads of acid or alkali. Journal of Clinical Investigation 44, 507-517.

Lemann, J. Jr \& Relman, R. S. (1959). The relation of sulfur metabolism to acid-base balance and electrolyte excretion: the effects of DL-methionione in normal man. Journal of Clinical Investigation 38, 2215-2223.

Linkswiler, H. M., Zemel, M. B., Hegsted, M. \& Schuette, S. (1981). Protein-induced hypercalciuria. Federation Proceedings 40, 2429-2433.

Livingstone, M. B. E., Prentice, A. M., Coward, W. A., Black, A. E., McKenna, P. G. \& Whitehead, R. G. (1990). Accuracy of weighed dietary records in studies of diet and health. British Medical Journal 300, 708712.

Lutz, J. (1984). Calcium balance and acid-base status of women as affected by increased protein intake and by sodium bicarbonate ingestion. American Journal of Clinical Nutrition 39, 281-288.

Maughan, R. J. (1978). The influence of diet and exercise on mammalian muscle metabolism. PhD Thesis, University of Aberdeen.

Paul, A. A. \& Southgate, D. A. T. (1983). McCance and Widdowson's The Composition of Foods, 3rd ed. London: H. M. Stationery Office.

Prentice, A. M., Coward, W. A. \& Davies, H. L. (1985). Unexpectedly low levels of energy expenditure in healthy women. Lancet i, 1419-1422.

Ramsdale, S. J. \& Bassey, E. J. (1994). Changes in bone mineral density associated with dietary-induced loss of body mass in young women. Clinical Science 87, 343-348.

Roberts, B. T. \& Mathers, J. C. (1990). Nutrient intakes by vegetarians in Newcastle Upon Tyne. Proceedings of the Nutrition Society 49, 93A.

Rose, B. D. (1977). Clinical Physiology of Acid-base and Electrolyte Disorders. Tokyo: McGraw-Hill.

Sakahee, K., Nicar, M., Hill, K. \& Pak, C. Y. C. (1983). Contrasting effects of potassium citrate and sodium citrate therapies on urinary chemistries and crystallization of stone-forming salts. Kidney International 24, 348-352.

Schofield, W. M., Schofield, C. \& James, W. P. T. (1985). Basal metabolic rate - review and prediction. Human Nutrition: Clinical Nutrition 39, Suppl., 1-96.

Sherman, H. C. (1941). Chemistry of Food and Nutrition, 6th ed. New York: Macmillan.

Sherman, H. C. \& Gettler, A. O. (1912). The balance of acid-forming elements in foods and its relation to ammonia metabolism. Journal of Biological Chemistry 11, 323-338.

Shohl, A. T. (1923). Mineral metabolism in relation to acid-base equilibrium. Physiology Reviews 3, 502-543.

Shultz, T. D. \& Leklem, J. E. (1983). Dietary status of Seventh-day Adventists and non-vegetarians. Journal of the American Dietetic Association 83, 27-33.

Siggaard-Andersen, O. (1963). Blood acid-base alignment normogram. Scandinavian Journal of Clinical Laboratory Investigation 15, 211-217.

Taber, L. A. L. \& Cook, R. A. (1980). Dietary and anthropometric assessment of adult omnivores, fish-eaters, and lacto-ovo-vegetarians. Journal of the American Dietetic Association 76, 21-29.

Tylavsky, F. A. \& Anderson, J. J. B. (1988). Dietary factors in bone health of elderly lacto-ovo-vegetarian and omnivorous women. American Journal of Clinical Nutrition 48, 842-849.

Wachman, A. \& Bernstein, D. S. (1968). Diet and osteoporosis. Lancet i, 958-959.

Wilson, E. D., Fisher, K. H. \& Fuqua, M. E. (1975). Principles of Nutrition, pp. 320-321. New York: Wiley and Sons. 